30,000 feet can be duplicated. The Bureau workers were the first to discover that a thin coating of pure aluminium greatly decreases the atmospheric corrosion of duralumin, an alloy largely used in aircraft construction. They worked out the very successful process of plating steel and other metals with chromium, the hardest metal known; this more than trebles the life of gauges, printing plates and similar devices. The Bureau developed the paper now used for printing U.S. paper currency, which has extended the total service life of such notes at least three times. It discovered that certain waste water from paper mills makes satisfactory material for tanning leather, and it established the dextrose (corn sugar) industry. It keeps the public well informed of its work, and its staff has increased by fifty times since it began in 1903.

Emoluments in the U.S. National Bureau of Standards

THE U.S. Department of Commerce has issued a circular giving a description of the scientific and technical positions in the National Bureau of Standards. It is pointed out that the Bureau affords an excellent opportunity for training in scientific work, and is in close touch with industrial research. Many employees have found their post an excellent stepping-stone to more highly remunerative work outside. It is an excellent post-graduate training ground, and outside interests are ever on the alert to secure successful research workers. All positions on the staff are subject to the competitive requirements of the civil service rules and regulations. The Bureau staff comprises about 775 professional, 'subprofessional', clerical, administrative and custodial positions. All appointments are made at the entrance salary of the grade for which eligibles have qualified by examination. Examinations for posts in the lower grades are held throughout the country in every large city. Applicants for the higher grades do not have to sit for a written examination; but are rated on their previous training and experience.

IN view of the present unemployment conditions in the United States, when any member of a single family living under one roof is in the service of the District of Columbia or of the United States Government, additional members of that family are not appointed. Assuming 5 dollars to the pound sterling, the following are a few of the rates of pay. In the 'professional service' which is the highest grade, there are eight divisions between 'junior' and 'chief'. A junior begins at $£ 400$ a year and ranges in seven steps to $£ 500$. A senior, which is the fifth grade, steps up from $£ 920$ to $£ 1,080$ and a 'chief' from $£ 1,600$ to $£ 1,800$. We are told that rentals for apartments and houses in the neighbourhood of the laboratories range upwards from about $£ 165$ a year, and that the eost of a room and board (two meals) is about $\mathfrak{f 1 0}$ a month.

\section{Protection of Antiquities in Nebraska}

$\mathrm{Br}$ a resolution of the State Legislature of Nebraska, police powers over sites of archæological and palæontological interest have been conferred on the
State Geological Survey, which will enablo that service to control tho future collection of antiquities and fossil bones, for which the State is widely known as a favourable locality. Although the efforts of the National Research Council have done much to make widely known among the people of the United States the desirability of preserving intact their monuments of antiquity, up to the present only a few of the States have taken legislative action to protect them ; and should the measures adopted in Nebraska prove effective, it is anticipated that other States will follow this example before long. As recent investigations have shown, Nebraska and the neighbouring States of the south-west are rich in relies of early man and of the extinet fauna with which, it would appear, early man was associated in this part of America ; but this wealth of material has proved an irresistible attraction to the amateur colloctor and the curio hunter, with the result that much important scientific evidence has been lost or destroyed by the removal of specimens from their stratigraphical context without adequate record, or indeed, in many instances, with no record at all. Some indications of the extent of the loss that science has suffered in this way is afforded by the references to important archæological specimens in private hands scattered throughout the records made by Prof. E. B. Renaud's archæological surveys of Colorado and adjacent territories. It has been specifically stated on behalf of the Geological Survey that there is no intention to restrict duly accredited scientific research.

\section{F. W. Hodge Anniversary Publication Fund}

IT is proposed to commemorate the services to anthropology of Dr. Frederick Webb Hodge, director of the South-West Museum, Los Angeles, during the fifty years in which he has been engaged in anthro. pological and archæological studies by the formation of a fund to assist in the publication of research work in the field of American prehistory. Dr. Hodge's career as an anthropologist began in 1886, when he joined the Hemenway South-western Archæological Expedition to Arizona. He became one of the pioneers in American anthropology, his best-known and undoubtedly most frequently consulted work being contained in the "Handbook of American Indians north of Mexico", of which he was editor and one of the principal contributors. He was one of the founders of the American Anthropological Association, editing its journal, the American Anthropologist, for the first fifteen years of its existence. He was for eight years head of the Bureau of American Ethnology, and has held his present office since 1932. The proposal for a publication fund to commemorate Dr. Hodge's long and strenuous career is put forward by a committee which is fully representative of the foremost anthropologists in the United States, including Dr. Aleš Hrdlička, Prof. F. Boas, Dr. Clark Wissler, Dr. A. V. Kidder, Dr. Fay-Cooper Cole, Dr. Bruno Oetteking, Dr. E. Sapir, and othors. The fund will be administered as an endowment trust by the South-western Museum, and managed by an editorial committes to be nominated by the appealing Committee. 